\title{
Climatic factors and their robust evidences controlling phytoplankton biomass in the Bransfield Strait
}

\author{
Hyoung Sul La ${ }^{1}$, Keyhong Park ${ }^{1, *}$, Jeong Yeob Chae ${ }^{1,2}$, Taewook Park ${ }^{1}$, and Jisoo Park ${ }^{1}$ \\ ${ }^{1}$ Division of Polar Ocean Sciences, Korea Polar Research Institute, Incheon, South Korea \\ ${ }^{2}$ Department of Ocean Sciences, Inha University, Incheon, South Korea
}

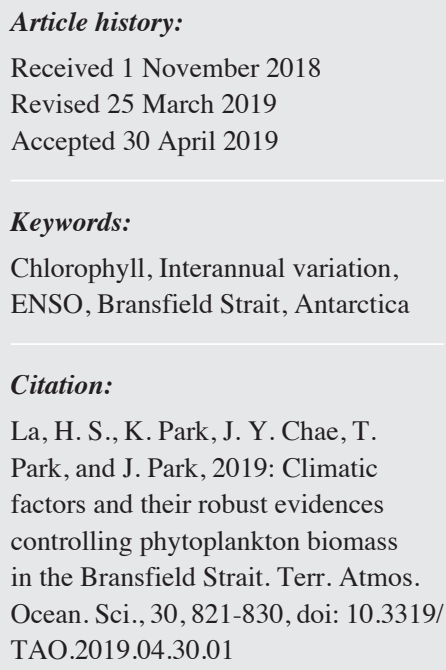

Citation:

La, H. S., K. Park, J. Y. Chae, T. Park, and J. Park, 2019: Climatic factors and their robust evidences controlling phytoplankton biomass in the Bransfield Strait. Terr. Atmos. Ocean. Sci., 30, 821-830, doi: 10.3319/ TAO.2019.04.30.01

\begin{abstract}
The long-term variability of chlorophyll $a(\mathrm{Chl}-a)$ was analyzed during a 12year period (2002 - 2014) in the Bransfield Strait, Antarctica, to assess the interannual variability of the Chl- $a$ and its main regulating environmental variables. We found that Chl- $a$ was significantly correlated with the El Niño Southern Oscillation (ENSO) phase $(r=-0.65)$, sea surface temperature (SST) $(r=0.70)$, and wind speed $(r=0.72)$, and changes in these factors preceded the Chl- $a$ change by $0-4$ months. High phytoplankton blooms (indicated by Chl- $a$ levels) tended to coincide with higher SSTs, and lagged with wind speed variation during La Niña periods. This suggests that atmospheric teleconnections with ENSO-related processes, SST, and wind speed could have a direct impact on phytoplankton biomass in the Bransfield Strait in short-term $(<4$ months) scales. Furthermore, our simple multivariable regression analysis showed the prominent possibility of using the three variables to predict Chl$a$ in the Bransfield Strait region. Overall, this study will help us to understand how atmospheric and oceanic fluctuations could affect phytoplankton dynamics in the Southern Ocean.
\end{abstract}

\section{INTRODUCTION}

The Antarctic Peninsula is the most rapidly changing region in the Southern Hemisphere, with a rise in atmospheric and ocean surface temperatures, and glacier retreat and thinning (Meredith and King 2005). The rapid environmental changes on the Antarctic Peninsula have resulted in changes in the adjacent marine ecosystem. The species and population distribution of marine organisms in this region have shown extreme sensitivity to the physical ocean environment (Peck et al. 2004). Biological productivity, inferred from phytoplankton biomass during summertime has significantly declined by $12 \%$ along the western shelf of the Antarctic Peninsula over the last 30 years with rapid regional climate change, which could impact the population of higher trophic levels, such as that of krill and penguins (Montes-Hugo et al. 2009).

The Bransfield Strait and adjacent waters west of the Antarctic Peninsula are one of the most productive areas in the Southern Ocean (Comiso et al. 1990; Sullivan et al.

\footnotetext{
* Corresponding author

E-mail:keyhongpark@kopri.re.kr
}

1993). Previous studies reported the role of phytoplankton (Arrigo et al. 1999) and water-column stratification for nutrient supply in ocean biological cycles (Platt et al. 2003a, b). Phytoplankton blooms in the Southern Ocean are frequently controlled by hydrographic features such as fronts (Laubscher et al. 1993), eddies (Heywood and Priddle 1987), upper mixed layer depths (Loeb et al. 2010; Gonçalves-Araujo et al.2015), and the seasonal sea ice extent and retreat (Smith et al. 1998). Spatial and temporal variation of phytoplankton distribution has often compared with complex water column structures (Basterretxea and Arístegui 1999). Additionally, a recent study suggested cloud cover influences phytoplankton biomass in the Southern Ocean (La and Park 2016). Longterm variation in phytoplankton biomass could be driven by climate change, such as the Southern Annular Mode (SAM) and El Niño Southern Oscillation (ENSO), since plankton ecosystems are associated with sea ice change and water column stability (Vernet et al. 2008; Venables et al. 2013). Plankton biomass near the northern Antarctic Peninsula has been controlled by fluctuations in ENSO of the southern frontal zone of the Antarctic Circumpolar Current (Loeb et 
al. 2009). Interpreting the long-term trends of plankton ecosystems requires an understanding of the link between biological and environmental systems. Because phytoplankton biomass has undergone a significant long-term change since the 1970s (Kim et al. 2018), it is necessary to update the previous studies with the recent and longer term environmental and climatic data sets to understand the complexity of phytoplankton biomass variation in the Southern Ocean region.

In the present study, we examined the long-term variability of the phytoplankton biomass in the Bransfield Strait to verify its correlation with climatic and environmental factors. The interannual variability of phytoplankton biomass over the defined Bransfield Strait was assessed by comparing oceanic variables [sea surface temperature (SST) and sea ice concentration (SIC)], climatic variables (SAM, ENSO), and atmospheric variables [cloud fraction, wind speed, and photosynthetically active radiation (PAR)] during the last 12 austral summer periods (2002 - 2014).

\section{METHODS}

\subsection{Study Region}

The Bransfield Strait is a semi-enclosed basin (Bárcena et al. 2002), located between the South Shetland Islands and the Antarctic Peninsula in the Southern Ocean (Fig. 1). The Bransfield Strait is composed of three deep basins (western, central, and eastern basins), which are distinguished from each other by $500 \mathrm{~m}$ deep sills (Gordon et al. 2000). The western basin is relatively shallower than the other two basins; the western basin reaches about $1000 \mathrm{~m}$, the central basin reaches about $2000 \mathrm{~m}$, the eastern basin reaches about $2500 \mathrm{~m}$. The Bransfield Strait is characterized by a complex hydrographic structure and a potential of high primary production during austral spring and summer (Bölter et al. 1988; Gordon et al. 2000). In order to assess the relative differences in chlorophyll $a(\mathrm{Chl}-a)$ concentrations between sub-regions, the study area was divided into a central and an eastern basin, as presented in Gordon et al. (2000). The central basin includes coastal water along the Antarctic Peninsula Shelf and the eastern basin includes both coastal water and oceanic waters in the Weddell Sea (Marrari et al. 2008).

\subsection{Chl- $a$ concentrations}

Surface Chl- $a$ concentrations were obtained from Moderate-Resolution Imaging Spectroradiometer (MODIS) chlorophyll satellite data from NASA Ocean Biology website for the period from January 2002 to December 2014 (http://oceandata.sci.gsfc.nasa.gov). Chl- $a$ is the main photosynthetic pigment, and thus can be used to represent phytoplankton biomass and primary productivity (Zhang et al. 2014). MODIS Aqua Level 3 monthly averaged data at a 4-km spatial resolution was used for only seven months (October to April) per year because of the limitation of ocean color data in the Southern Ocean. Additionally, because the Bransfield Strait is divided into two regions which are central and eastern basin, we took a look the difference of Chl- $a$ variation trend in the two basins (Fig. 2). A time series analysis of monthly averaged Chl- $a$ showed that there were no significant seasonal and/or interannual differences between the eastern and central basins of Bransfield Strait. Climatological monthly average of Chl- $a$ between 2003 and 2015 also showed no significant regional differences within one standard deviation between two regions (supplementary Fig. S1). Therefore, we assumed the variation of Chl- $a$ biomass in the entire the Bransfield Strait is under the one

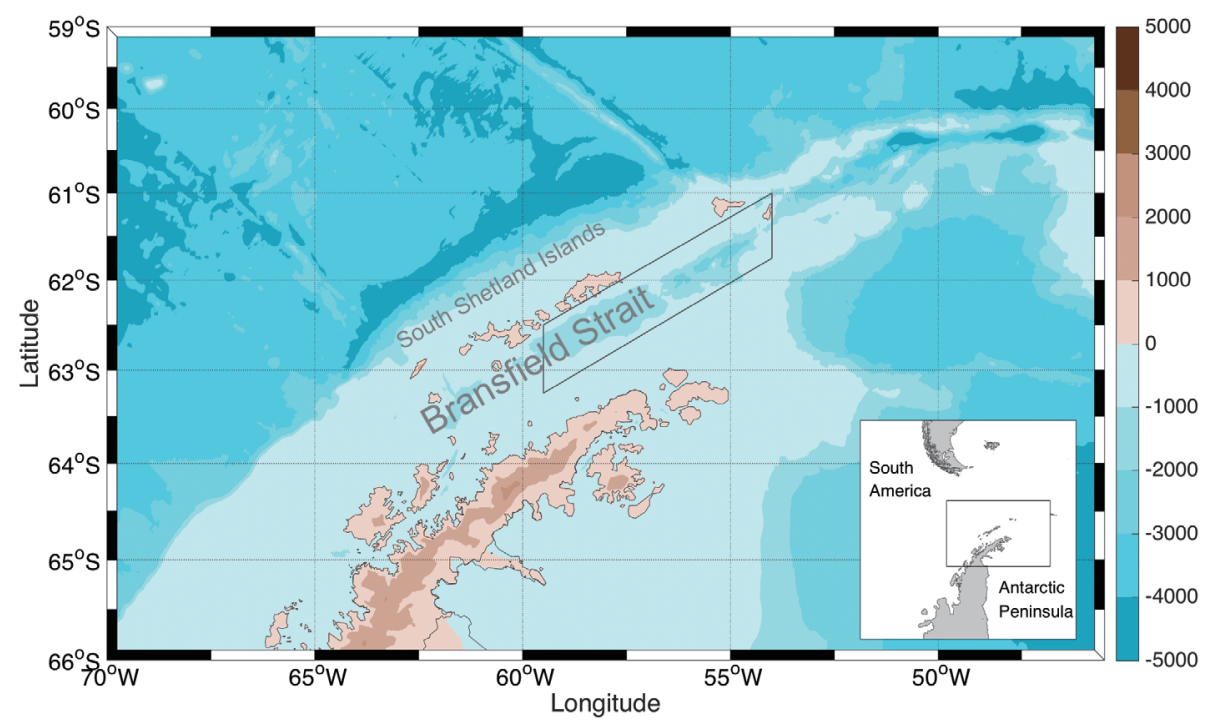

Fig. 1. The bathymetry map of the Bransfield Strait in the Southern Ocean. The study region is indicated in the parallelogram. The inset map depicts the position of the Antarctic Peninsula. 
(a)
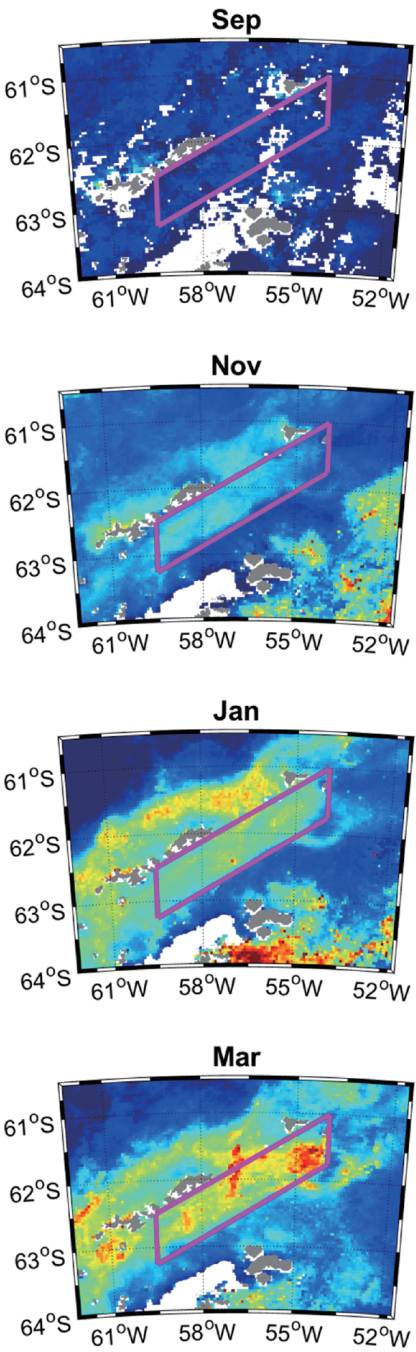
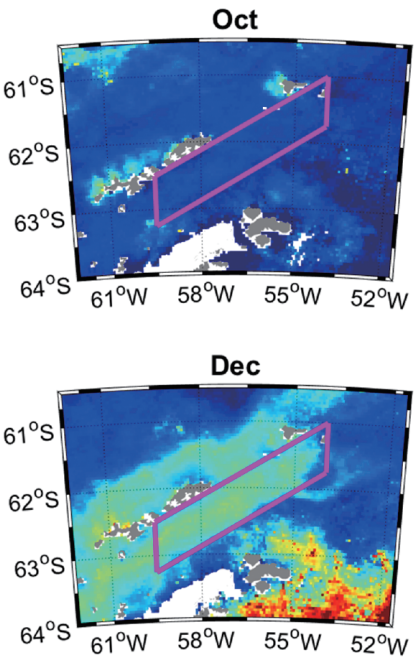

Feb
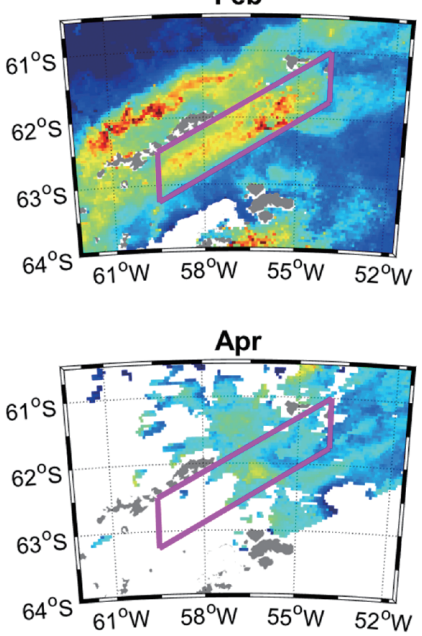

(b)
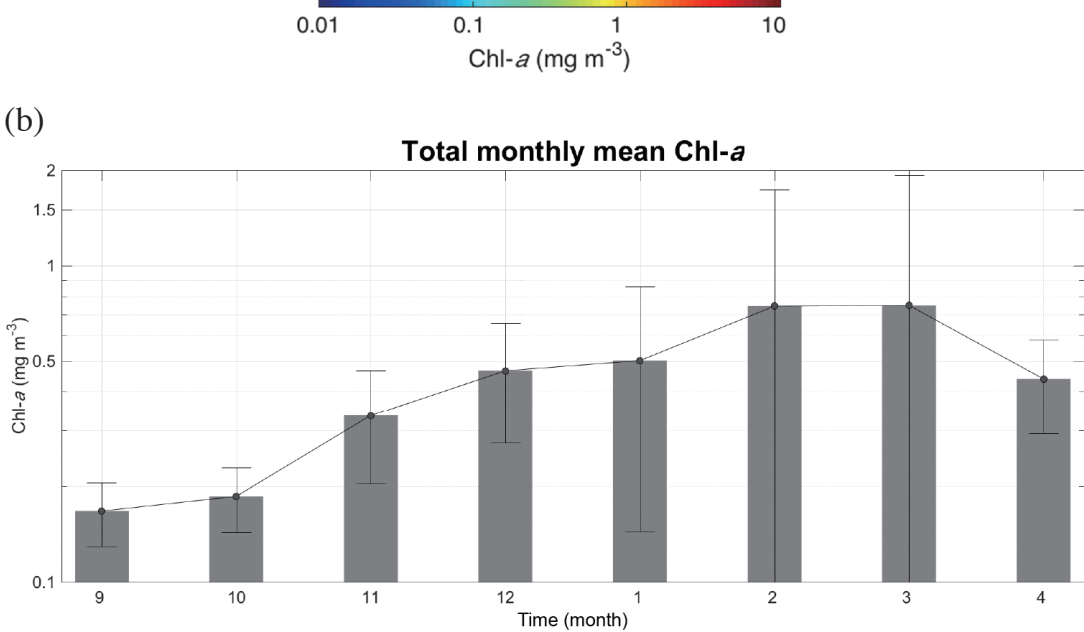

Fig. 2. (a) Monthly Chl- $a$ climatology around the Bransfield Strait (purple square) of the Southern Ocean (12-year mean). The color shows the MODIS Chl- $a$ concentration calculated by a standard algorithm. The white region indicates data limited by sea ice, the presence of clouds, and low solar elevation. (b) Monthly Chl- $a$ within the Bransfield Strait over the 12-year period. 
marine system and, in this study, we used the averaged Chl$a$ from the both basins.

\subsection{Oceanographic Parameters}

Monthly averaged sea ice concentration (SIC) was retrieved from the National Oceanic and Atmospheric Administration (NOAA)/National Snow and Ice Data Center (NSIDC) with nominal $25 \mathrm{~km} \times 25 \mathrm{~km}$ grid cells in the study region (http://nsidc.org/data/G02202). Monthly averaged SST was provided by a daily Group for High-Resolution SST (GHRSST) Level 4 with a spatial resolution of 0.2 degrees (https://podaac.jpl.nasa.gov/dataset) (supplementary Fig. S2).

\subsection{Climatic and Atmospheric Indices}

To investigate the climate effect on Chl- $a$ biomass, we used two climatic indices: the Oceanic Niño Index (ONI) for ENSO and SAM. The monthly SAM index was available on the BAS website (http://www.nerc-bas.ac.uk/icd/ gima/sam.html), which was based on the methodology in Marshall (2003). The ONI was obtained from the Climate Prediction Center (CPC, http://www.cpc.ncep.noaa.gov).

Cloud fraction and PAR were retrieved from the $\mathrm{Eu}-$ ropean Centre for Medium-Range Weather Forecasts (ECMWF) ERA-Interim reanalysis (Dee et al. 2011). ERAInterim shows a good performance for solar radiation and cloud fraction among the current representative global reanalysis (Zhang et al. 2016). The horizontal resolution was $0.75^{\circ} \times 0.75^{\circ}$, and each parameter was calculated for the monthly mean over this study's pre-defined Bransfield Strait (Fig. 1). Based on the atmospheric pressure, 122 heights of cloud fraction data were defined as low-level (1 - 0.8 sigma; sigma $=123$ pressure $/$ surface pressure $)$, midlevel (0.8 - 0.45 sigma), and high-level ( $<0.45$ sigma) cloud in the ERA-Interim (supplementary Fig. S2).

\section{RESULTS AND DISCUSSION}

Climatology patterns of the monthly Chl- $a$ concentration from July 2002 through December 2014 indicated that the Bransfield Strait had persistently enhanced Chl- $a$ during late spring through early fall with high spatio-temporal variability; high standard deviation, especially in February and March (Fig. 2). Chl- $a$ in the Bransfield Strait began to increase from November, and blooms continued from December to March. Phytoplankton blooms exceeding $5.0 \mathrm{mg} \mathrm{m}^{-3}$ occurred during February and March and rapidly decreased in April. The spatial and temporal changes in Chl- $a$ indicate that phytoplankton biomass accumulations initially occurred during November around the South Shetland Islands and Elephant Island. As the season progressed, phytoplankton blooms developed in the northern area of the South Shetland
Islands from January and February (Fig. 2a). On the other hand, the phytoplankton blooms in the Bransfield Strait intensified in February and remained until to March. These could be associated with the timing of sea-ice extent retreat, which began to decrease around October and was at a minimum in February (Park et al. 2010).

The seasonal and interannual variability in the monthly Chl- $a$ concentration within the study region is clearly shown in Figs. 3 and 4. Chl- $a$ was highly variable over the period investigated, but phytoplankton blooms occurred consistently between November and March each year. The strength of phytoplankton blooms during austral summers showed clear interannual variability from the January, February, and March (hereafter as JFM) mean Chl- $a$ over the 12-year period investigated (Fig. 3). High phytoplankton biomass $>1 \mathrm{mg} \mathrm{m}^{-3}$ occurred during 2006, 2011, and 2012, whereas low phytoplankton biomass $<0.5 \mathrm{mg} \mathrm{m}^{-3}$ occurred during 2003, 2004, 2010, and 2014. An intense bloom with a mean Chl- $a$ concentration of $1.2 \mathrm{mg} \mathrm{m}^{-3}$ appeared in 2011.

The phytoplankton biomass seemed to strongly respond to certain trends in climate variability. The annual cycles of phytoplankton fluctuations have also been associated with variability in vertical stratification, wind mixing, macronutrient amounts, sea ice concentration, and solar irradiance for phytoplankton growth (Smith et al. 2000). To examine the interannual variability of phytoplankton biomass with variations of climatic variables, we analyzed the Pearson correlation between the mean Chl- $a$ concentration (JFM) and climatic indices (ONI and SAM) with a time lag (0 - 6 months) (supplementary Fig. S3 and Table 1).

The phytoplankton biomass showed a significant correlation $(p<0.05)$ with $2-6$ months lagged ONI, and the maximum correlation was obtained with a 4-month lagged ONI $(r=-0.65)$, whereas it showed an obviously weak and insignificant correlation with SAM $\left(r_{\max }=0.51, p=0.09\right.$ with a 4-month lag). In general, the influence of SAM is stronger than ENSO in the Southern Ocean climate variability. However, because the Antarctic Peninsula is located in between the Amundsen - Bellingshausen Sea and Weddell Sea and in relatively lower latitude, the region is under the complex climate system including the Amundsen low, which influenced by ENSO and SAM in tandem (Clem et al. 2016, 2017). The result in this study indicates ENSO is more essential driver of climate variability.

Thus, the phytoplankton biomass was negatively correlated with ENSO; moreover, the high phytoplankton biomass within Bransfield Strait was associated with a strong La Niña period (supplementary Fig. S3b). Smith et al. (2008) also observed that a high Chl- $a$ biomass offshore in the western Antarctic Peninsula region was associated with La Niña.

Phytoplankton biomass closely varied with some environmental factors as well. Chl- $a$ (JFM) exhibited a strong correlation with SST $(r=0.7, p<0.05)$ and wind speed $(r$ 


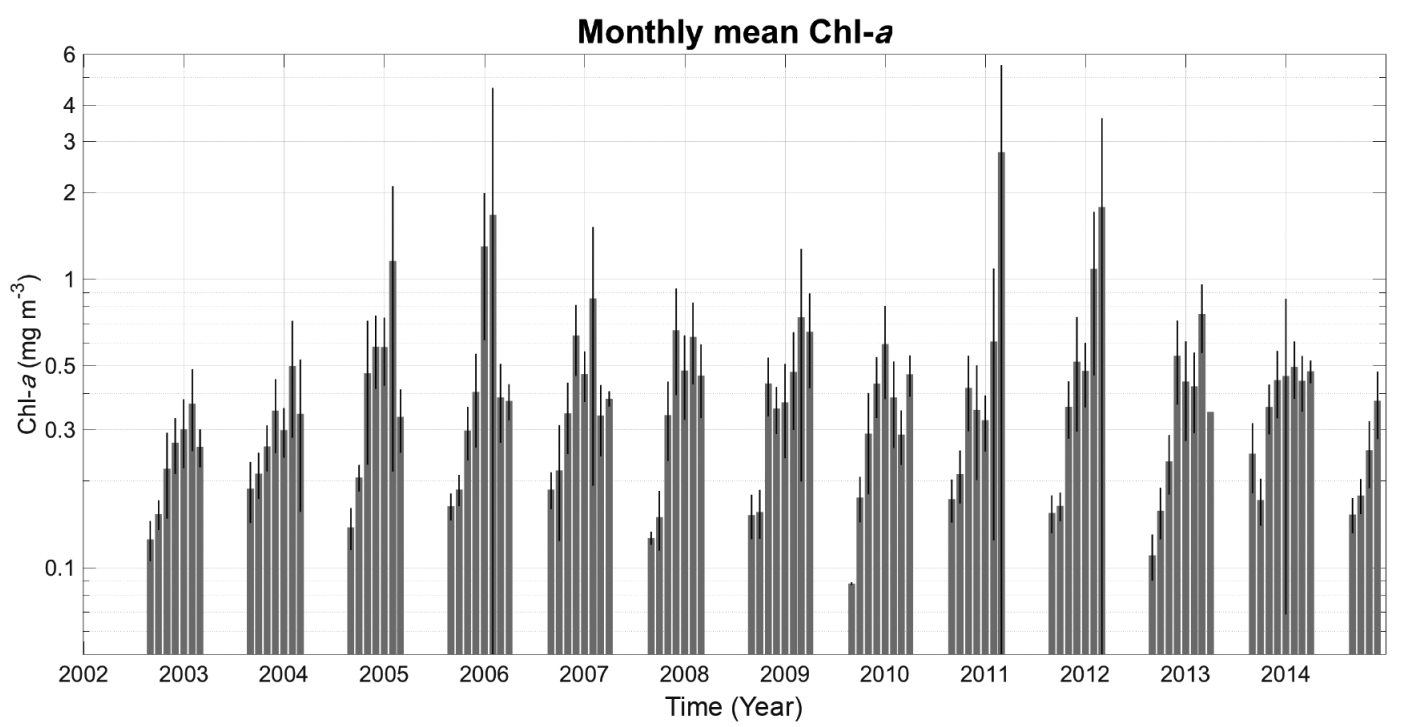

Fig. 3. Time-series analysis of the Chl- $a$ concentration over 150 months within the Bransfield Strait from July 2002 to December 2014.

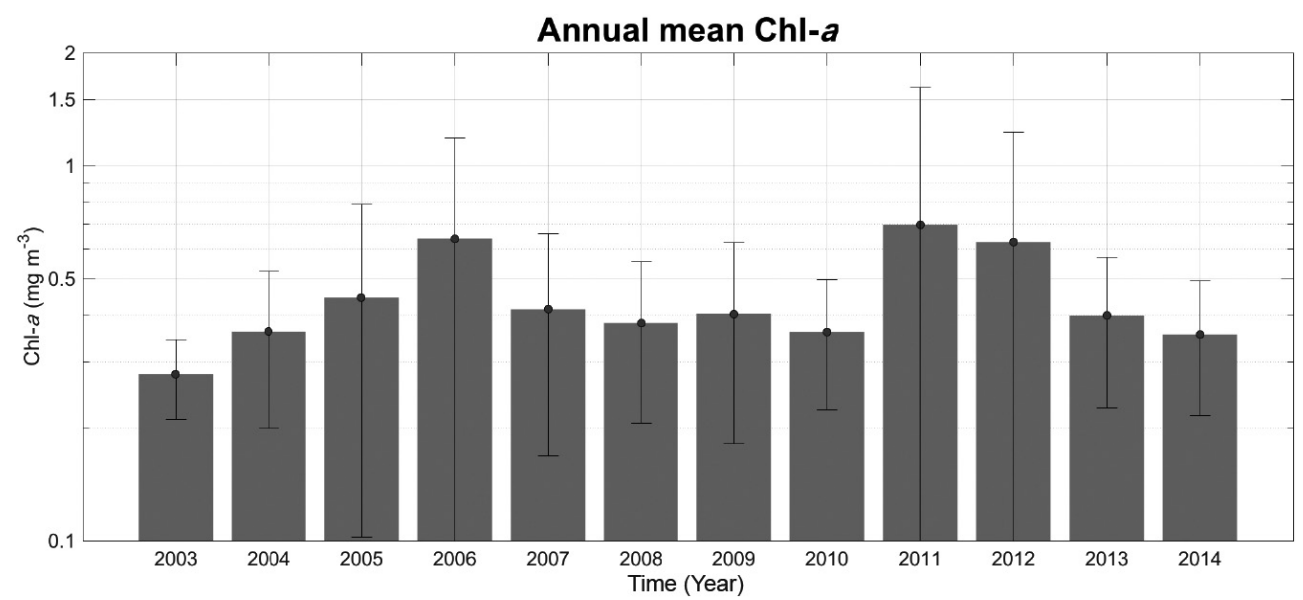

Fig. 4. Interannual variation of averaged Chl- $a$ in the Bransfield Strait during the austral summer (JFM), considering the data from July 2002 to December 2014. The error bars denote the 1- $\sigma$ of the three months (JFM).

Table 1. Correlation coefficients between phytoplankton biomass $(\mathrm{Chl}-a)$ and environmental variables [ONI, SAM, PAR, SIC, SST, and wind speed (WS)] with a time lag (0 - 6 months).

\begin{tabular}{c|cccccccc}
\hline & \multicolumn{7}{|c}{ Correlation coefficients with a time lag } \\
\cline { 2 - 9 } & $\mathbf{0}$ & $\mathbf{1}$ & $\mathbf{2}$ & $\mathbf{3}$ & $\mathbf{4}$ & $\mathbf{5}$ & $\mathbf{6}$ \\
\hline ONI & -0.51 & -0.56 & $-0.61^{*}$ & $-0.64^{*}$ & $-0.65^{*}$ & $-0.64^{*}$ & $-0.62^{*}$ \\
SAM & 0.05 & -0.01 & 0.22 & 0.39 & 0.51 & 0.43 & 0.20 \\
PAR & 0.31 & 0.06 & -0.17 & -0.34 & -0.22 & -0.06 & -0.01 \\
SIC & -0.25 & -0.27 & -0.32 & -0.39 & -0.20 & -0.11 & -0.09 \\
SST & $0.70^{*}$ & $0.66^{*}$ & $0.67^{*}$ & $0.65^{*}$ & 0.46 & 0.15 & 0.01 \\
WS & 0.35 & 0.48 & $0.69^{*}$ & $0.72^{*}$ & 0.42 & -0.14 & -0.24 \\
\hline
\end{tabular}

Note: $*$ Significance at $p<0.05$. 
$=0.72, p<0.05$ ) within a 0 - and 3-month lag, respectively (Fig. 5). The variation of SST and phytoplankton biomass could be directly caused by ENSO (Zhang et al. 2014), and SST is one of the main factors controlling phytoplankton biomass (Behrenfeld and Falkowski 1997). As the southern westerly winds drive the Antarctic Circumpolar Current (ACC) around Antarctica, deep waters are forced up to the surface south of the polar front. The westerly winds around the Antarctic continent result in an upwelling region, the Antarctic Divergence at the Southern Front, which is considered to be the Antarctic Circumpolar Current Southern Boundary (ACCSB). The ACCSB is at approximately $65^{\circ} \mathrm{S}$ (Orsi et al. 1995) moving northward to $55^{\circ} \mathrm{S}$. During La Niña the wind strengthens, driving warm, wet storms south across the Southern Ocean, which reduce the sea ice extent along the West Antarctic Peninsula. La Niña drives enhanced upwelling in this region (Martinson et al. 2008). Moreover, a strengthened westerly wind can lead to an increase in the upwelling of subsurface water during austral summer (Purich et al. 2016). Since deep mixing of the Antarctic Surface Water (AASW) occurs during winter months, changes in the intensity with which this relatively warm, nutrient-rich, and $\mathrm{CO}_{2}$-enriched Circumpolar Deep Water upwells has significant implications for primary productivity (Deppeler and Davidson 2017) during phytoplankton blooming season. Upwelled nutrient-rich water would fertilize the phytoplankton blooms. Enhanced phytoplankton blooms in surface waters have also been linked with upwelling of iron-rich shelf bottom water (Trimborn et al. 2015).

Furthermore, we performed time lag correlation analyses with other environmental variables influencing Chl- $a$ as well, which includes SIC, PAR, and cloud cover (supplementary Fig. S3). However, no pronounced relationships were observed among these variables with Chl- $a$ in the Bransfield Strait. In contrast to La and Park (2016) who presented robust correlations between cloud cover, cloud height, or PAR with Chl- $a$ in the Antarctic coastal polynyas, the weak correlations in the present study implied that light condition is not a key limiting factor for chlorophyll in the Bransfield Strait. Note that the response of Chl- $a$ to the high cloud fraction was opposite to the middle and low cloud fractions, albeit their moderate to weak correlations (supplementary Figs. S3h - j). The increase in high cloud cover enhanced Chl- $a$, and the increase in middle or low cloud cover reduced Chl- $a$. This implies a different role of cloud height to the Chl- $a$ variation, as well as the complex influence of future cloud cover change associated with climate change (Nazarenko et al. 2015) to the Chl- $a$ biomass level. Additionally, the weak correlation between Chl- $a$ and $\operatorname{SIC}\left(r_{\max }=-0.39, p=0.21\right.$ with a 3-month lag $)$ indicated that sea ice-related nutrient or iron release (Wang et al. 2014) was not directly linked to Chl- $a$ in this region.

Therefore, we selected the 4-month lagged ONI, 0 -month lagged SST, and 3-month lagged wind speed, that exhibited the most robust correlation with Chl- $a$, as the main environmental drivers to the phytoplankton biomass in the Bransfield Strait region (Fig. 5).

We investigated to find a possibility of using these three variables [SST, ONI, and wind speed (WS)] to pre$\operatorname{dict} \mathrm{Chl}-a$, since the variation of these factors occurred 0 - 4 months preceding the Chl- $a$ change. Assuming Chl- $a$ can be estimated by SST, ONI, and WS, and each variable has a linear relationship with Chl- $a$ [Eq. (1)], we performed multiple multivariable linear regression analyses.

$\mathrm{CHL}=f(\mathrm{SST}, \mathrm{ONI}, \mathrm{WS})$

where SST, ONI, WS denoted 0-, 4-, and 3-month lagged variables.

Each multivariable regression was performed based on the Jackknife sampling which is selecting twelve 11-year
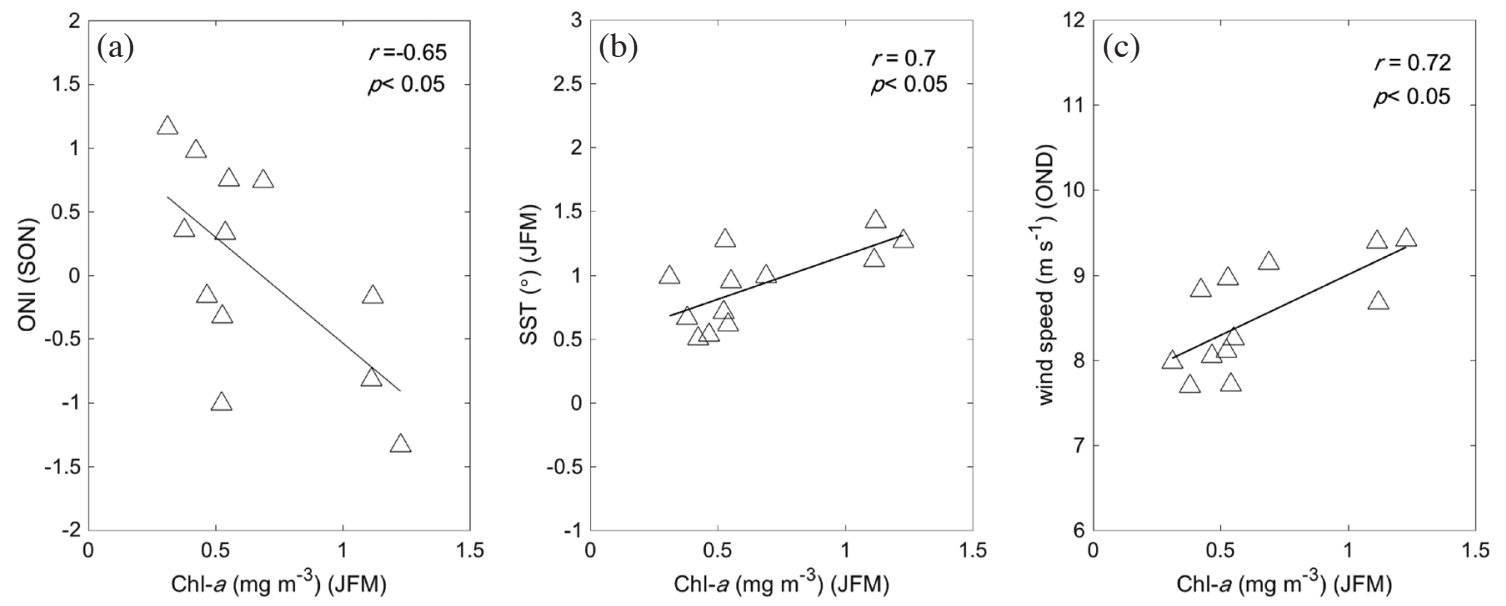

Fig. 5. Scatterplots showing the Chl- $a$ concentration against the climatic indices throughout the study period (2002 - 2014): (a) 4-month lagged Oceanic Niño Index (ONI), (b) 0-month lagged Sea Surface Temperature (SST), and (c) 3-month lagged surface wind speed. 
data sets (Chl- $a$, SST, ONI, and WS) out of the 12-year data sets $(2003$ - 2014), and then the coefficients of the multivariable regression curves were calculated by Eq. (2).

$$
\hat{\mathrm{b}}=\left(\boldsymbol{X}^{\prime} \boldsymbol{X}\right)^{-1} \boldsymbol{X}^{\prime} \boldsymbol{Y}
$$

where $n$ is the number of years used for the regression $(n=$ 11) and

$\mathbf{b}=\left[\begin{array}{c}\mathrm{b}_{0} \\ \mathrm{~b}_{1} \\ \mathrm{~b}_{2} \\ \mathrm{~b}_{3}\end{array}\right], \boldsymbol{X}=\left[\begin{array}{cccc}1 & \mathrm{SST}_{1} & \mathrm{ONI}_{1} & \mathrm{WS}_{1} \\ \vdots & \vdots & \vdots & \vdots \\ 1 & \mathrm{SST}_{n} & \mathrm{ONI}_{n} & \mathrm{WS}_{n}\end{array}\right]$ and $\boldsymbol{Y}=\left[\begin{array}{c}\mathrm{CHL}_{1} \\ \vdots \\ \mathrm{CHL}_{n}\end{array}\right]$

We set aside one-year data set to evaluate the predictability of the empirical multivariable regression. The regression result [Eq. (2)] is applied to estimate the Chl- $a$ of the remaining year using the Eq. (4) and repeated for all 12 years.

$$
\mathrm{CHL}_{t}=b_{0}+b_{1}\left(\mathrm{SST}_{t}\right)+b_{2}\left(\mathrm{ONI}_{t}\right)+b_{3}\left(\mathrm{WS}_{t}\right)
$$

where $t$ denotes a year selected for evaluation and $\overline{\mathrm{CHL}}_{t}$ is the predicted Chl- $a$ derived from the multivariable regression analysis.
In Fig. 6, the predicted mean JFM Chl- $a$ values were compared to the Chl- $a$ retrieved from the satellite. The predicted values showed a strong positive correlation $(r=0.71$, $p<0.01)$ with the observation, and thus implied that SST, ONI, and WS are variables closely associated with Chl- $a$ in the Bransfield Strait. In addition, this suggests that the three variables could be used to predict the Chl- $a$ level across environments similar to ones found in the Bransfield Strait. In fact, the robust relationship in Fig. 6 was noticeable during the low Chl- $a$ years, whereas the regressions underestimated the high Chl- $a$ years.

\section{DISCUSSION AND CONCLUSION}

We performed the same multivariable regression analyses for 2003 - 2015 and 2003 - 2016 (supplementary Fig. S4). Extrapolating until 2015 exhibited almost identical results to the estimates presented in Fig. 6. However, once the 2016 data sets are added in the analysis, the correlation between the model estimates and true values reduced to $r=$ 0.71 to 0.58 . An ONI index applied for 2016's estimate is 2.33 while the mean ONI index between 2003 and 2014 is $0.04 \pm 0.81$. Therefore, different to the previous 12 years, the 2016 's result was presumably affected by the extraordinary strong El Niño, and thus the phytoplankton biomass estimate was limited by the description of current model. This also suggests that more robust estimates will be able to acquire

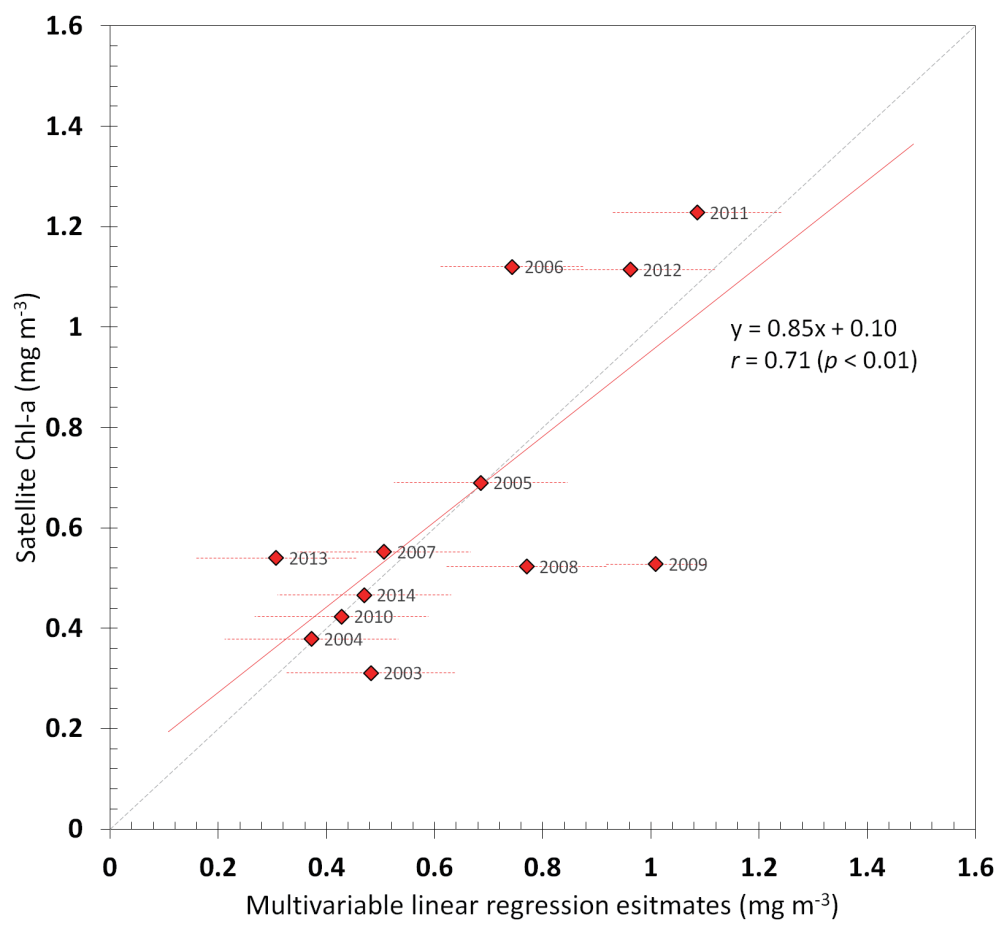

Fig. 6. Correlation between the mean JFM satellite Chl- $a$ in the Bransfield Strait and its predicted estimates calculated from the empirical multivariable regression analysis. Each data point is the predicted value for a particular year from the multivariable regression line derived from the data of 12 austral summer periods (2003 - 2014). The error bars are the root mean squared errors (RMSE) of each multivariable regression curve from the 11-year input. The solid red line is the linear regression line and the dotted grey line is the 1-to-1 relation between the predicted and satellite Chl- $a$. 
by accumulating input data sets with extended time periods covering wider climate and environment variabilities.

The western Antarctic Peninsula has been experienced a dramatic warming trend with a clear interannual variability. The surface temperature has increased by approximately $3^{\circ} \mathrm{C}$ over the past 50 years (Vaughan et al. 2001). Phytoplankton variability is an essential key driver of the marine ecosystem as a sensitive biological indicator of climate change. Interannual variability of phytoplankton biomass is finely tuned in synchrony with the variation of climatic, atmospheric, and oceanic variables around the fastest warming areas on earth, the Antarctic Peninsula. An ENSO-induced atmospheric variability influences a strength of northwest winds and ocean current in the study area. During La Niña events, strong northwest winds and associated poleward movement of the Southern Antarctic Circumpolar Current Front tends to increase chlorophyll-a concentrations via upwelling and mixing between oceanic and coastal waters, and vice versa during El Niño events (Sprintall 2003; Loeb et al. 2010). The strong negative correlation between ONI index and chlorophyll-a concentration suggests an important role of the ENSO-related large-scale forcing on phytoplankton dynamics. Sea surface temperature is another regional factor that controls Chl- $a$ concentrations by altering metabolic rates. For example, studies of Antarctic phytoplankton indicate that temperature alone causes increase of the growth rate (Boyd et al. 2013; Petrou et al 2016). Strong winds deepen mixed layer depth through turbulent mixing, thereby increasing phytoplankton growth by bringing nutrient-rich water to the surface (Abbott et al. 2000; Deppeler and Davidson 2017). Our results for a decadal dataset revealed that the phytoplankton biomass undergoes clear seasonal and interannual dynamics. The potential ecological responses, such as biogeochemical variability could vary in this region, depending on the relative interannual variability of climate cycles and other environmental drivers with phytoplankton variability. Therefore, understanding the relationship between climatic factors and phytoplankton biomass is important to forecast the dynamics of the marine ecosystem in the western Antarctic Peninsula. Our results emphasized the long-term trend of phytoplankton biomass to clarify the relationship between phytoplankton biomass and climatic, atmospheric, and oceanic variables. Furthermore, the phytoplankton biomass in the Bransfield Strait increased with higher surface temperatures and wind speeds during La Niña periods, and this trend was especially clear during the low phytoplankton years.

Acknowledgements This work was supported by Korea Polar Research Institute (PE19060 and PE 19070) and additional data processing and analysis was supported by a grant from (PE 19200). All datasets used in this paper are available upon request from the corresponding author (keyhongpark@kopri.re.kr).

\section{REFERENCES}

Abbott, M. R., J. G. Richman, R. M. Letelier, and J. S. Bartlett, 2000: The spring bloom in the Antarctic Polar Frontal Zone as observed from a mesoscale array of bio-optical sensors. Deep-Sea Res. Part II-Top. Stud. Oceanogr., 47, 3285-3314, doi: 10.1016/S09670645(00)00069-2. [Link]

Arrigo, K. R., D. H. Robinson, D. L. Worthen, R. B. Dunbar, G. R. DiTullio, M. VanWoert, and M. P. Lizotte, 1999: Phytoplankton community structure and the drawdown of nutrients and $\mathrm{CO}_{2}$ in the Southern Ocean. Science, 283, 365-367, doi: 10.1126/science.283.5400.365. [Link]

Bárcena, M. Á., E. Isla, A. Plaza, J. A. Flores, F. J. Sierro, P. Masqué, J. A. Sanchez-Cabeza, and A. Palanques, 2002: Bioaccumulation record and paleoclimatic significance in the Western Bransfield Strait. The last 2000 years. Deep-Sea Res. Part II-Top. Stud. Oceanogr., 49, 935-950, doi: 10.1016/S0967-0645(01)00132-1. [Link]

Basterretxea, G. and J. Arístegui, 1999: Phytoplankton biomass and production during late austral spring (1991) and summer (1993) in the Bransfield Strait. Polar Biol., 21, 11-22, doi: 10.1007/s003000050328. [Link]

Behrenfeld, M. J. and P. G. Falkowski, 1997: Photosynthetic rates derived from satellite-based chlorophyll concentration. Limnol. Oceanogr., 42, 1-20, doi: 10.4319/ lo.1997.42.1.0001. [Link]

Bölter, M., B. von Bodungen, G. Liebezeit, and M. Meyer, 1988: The pelagic ecosystem of the Bransfield Strait, Antarctica: An analysis of microbiological, planktological and chemical characteristics by multivariate analyses. In: Sahrhage, D. (Ed.), Antarctic Ocean and Resources Variability, Springer, Berlin, Heidelberg, 160-166, doi: 10.1007/978-3-642-73724-4_13. [Link]

Boyd, P. W., T. A. Rynearson, E. A. Armstrong, F. Fu, K. Hayashi, Z. Hu, D. A. Hutchins, R. M. Kudela, E. Litchman, M. R. Mulholland, U. Passow, R. F. Strzepek, K. A. Whittaker, E. Yu, and M. K. Thomas, 2013: Marine phytoplankton temperature versus growth responses from polar to tropical waters - outcome of a scientific community-wide study. PLOS ONE, 8, e63091, doi: 10.1371/journal.pone.0063091. [Link]

Clem, K. R., J. A. Renwick, J. McGregor, and R. L. Fogt, 2016: The relative influence of ENSO and SAM on Antarctic Peninsula climate. J. Geophys. Res., 121, 9324-9341, doi: 10.1002/2016JD025305. [Link]

Clem, K. R., J. A. Renwick, and J. McGregor, 2017: Largescale forcing of the Amundsen Sea Low and its influence on sea ice and West Antarctic temperature. J. Climate, 30, 8405-8424, doi: 10.1175/JCLI-D-16-0891.1. [Link]

Comiso, J. C., N. G. Maynard, W. O. Smith, and C. W. Sullivan, 1990: Satellite ocean color studies of Antarctic 
ice edges in summer and autumn. J. Geophys. Res., 95, 9481-9496, doi: 10.1029/JC095iC06p09481. [Link]

Dee, D. P., S. M. Uppala, A. J. Simmons, P. Berrisford, P. Poli, S. Kobayashi, U. Andrae, M. A. Balmaseda, G. Balsamo, P. Bauer, P. Bechtold, A. C. M. Beljaars, L. van de Berg, J. Bidlot, N. Bormann, C. Delsol, R. Dragani, M. Fuentes, A. J. Geer, L. Haimberger, S. B. Healy, H. Hersbach, E. V. Hólm, L. Isaksen, P. Kållberg, M. Köhler, M. Matricardi, A. P. McNally, B. M. Monge-Sanz, J.-J. Morcrette, B.-K. Park, C. Peubey, P. de Rosnay, C. Tavolato, J.-N. Thépaut, and F. Vitart, 2011: The ERA-Interim reanalysis: Configuration and performance of the data assimilation system. $Q . J$. R. Meteorol. Soc., 137, 553-597, doi: 10.1002/qj.828. [Link]

Deppeler, S. L. and A. T. Davidson, 2017: Southern Ocean Phytoplankton in a Changing Climate. Front. Mar. Sci., 4, doi: 10.3389/fmars.2017.00040. [Link]

Gonçalves-Araujo, R., M. S. de Souza, V. M. Tavano, and C. A. E. Garcia, 2015: Influence of oceanographic features on spatial and interannual variability of phytoplankton in the Bransfield Strait, Antarctica. J. Mar. Syst., 142, 1-15, doi: 10.1016/j.jmarsys.2014.09.007. [Link]

Gordon, A.L., M. Mensch, D.Zhaoqian, W. M. Smethie, and J. de Bettencourt, 2000: Deep and bottom water of the Bransfield Strait eastern and central basins. J. Geophys. Res., 105, 11337-11346, doi: 10.1029/2000JC900030. [Link]

Heywood, R. B. and J. Priddle, 1987: Retention of phytoplankton by an eddy. Cont. Shelf Res., 7, 937-955, doi: 10.1016/0278-4343(87)90007-0. [Link]

Kim, H., H. W. Ducklow, D. Abele, E. M. Ruiz Barlett, A. G. J. Buma, M. P. Meredith, P. D. Rozema, O. M. Schofield, H. J. Venables, and I. R. Schloss, 2018: Inter-decadal variability of phytoplankton biomass along the coastal West Antarctic Peninsula. Phil. Trans. Math. Phys. Eng. Sci., 376, 20170174, doi: 10.1098/ rsta.2017.0174. [Link]

La, H. S. and K. Park, 2016: The evident role of clouds on phytoplankton abundance in Antarctic coastal polynyas. Terr. Atmos. Ocean. Sci., 27, 293-301, doi: 10.3319/TAO.2015.11.30.01(Oc). [Link]

Laubscher, R. K., R. Perissinotto, and C. D. McQuaid, 1993 : Phytoplankton production and biomass at frontal zones in the Atlantic sector of the Southern Ocean. Polar Biol., 13, 471-481, doi: 10.1007/BF00233138. [Link]

Loeb, V. J., E. E. Hofmann, J. M. Klinck, O. Holm-Hansen, and W. B. White, 2009: ENSO and variability of the Antarctic Peninsula pelagic marine ecosystem. Antarct. Sci., 21, 135-148, doi: 10.1017/S0954102008001636. [Link]

Loeb, V. J., E. E. Hofmann, J. M. Klinck, and O. HolmHansen, 2010: Hydrographic control of the marine ecosystem in the South Shetland-Elephant Island and Bransfield Strait region. Deep-Sea Res. Part IITop. Stud. Oceanogr., 57, 519-542, doi: 10.1016/j. dsr2.2009.10.004. [Link]

Marrari, M., K.L. Daly, and C. Hu, 2008: Spatial and temporal variability of SeaWiFS chlorophyll $a$ distributions west of the Antarctic Peninsula: Implications for krill production. Deep-Sea Res. Part II-Top. Stud. Oceanogr., 55, 377-392, doi: 10.1016/j.dsr2.2007.11.011. [Link]

Marshall, G. J., 2003: Trends in the Southern Annular Mode from observations and reanalyses. J. Climate, 16, 41344143, doi: 10.1175/1520-0442(2003)016<4134:TITS $\mathrm{AM}>2.0 . \mathrm{CO} ; 2$. [Link $]$

Martinson, D. G., S. E. Stammerjohn, R. A. Iannuzzi, R. C. Smith, and M. Vernet, 2008: Western Antarctic Peninsula physical oceanography and spatio-temporal variability. Deep-Sea Res. Part II-Top. Stud. Oceanogr., 55, 1964-1987, doi: 10.1016/j.dsr2.2008.04.038. [Link]

Meredith, M. P. and J. C. King, 2005: Rapid climate change in the ocean west of the Antarctic Peninsula during the second half of the 20th century. Geophys. Res. Lett., 32, doi: 10.1029/2005GL024042. [Link]

Montes-Hugo, M., S. C. Doney, H. W. Ducklow, W. Fraser, D. Martinson, S. E. Stammerjohn, and O. Schofield, 2009: Recent changes in phytoplankton communities associated with rapid regional climate change along the western Antarctic Peninsula. Science, 323, 1470 1473, doi: 10.1126/science.1164533. [Link]

Nazarenko, L., G. A. Schmidt, R. L. Miller, N. Tausnev, M. Kelley, R. Ruedy, G. L. Russell, I. Aleinov, M. Bauer, S. Bauer, R. Bleck, V. Canuto, Y. Cheng, T. L. Clune, A. D. Del Genio, G. Faluvegi, J. E. Hansen, R. J. Healy, N. Y. Kiang, D. Koch, A. A. Lacis, A. N. LeGrande, J. Lerner, K. K. Lo, S. Menon, V. Oinas, J. Perlwitz, M. J. Puma, D. Rind, A. Romanou, M. Sato, D. T. Shindell, S. Sun, K. Tsigaridis, N. Unger, A. Voulgarakis, M.-S. Yao, and J. Zhang, 2015: Future climate change under RCP emission scenarios with GISS ModelE2. J. Adv. Model. Earth Syst., 7, 244-267, doi: 10.1002/2014MS000403. [Link]

Orsi, A. H., T. Whitworth, and W. D. Nowlin, 1995: On the meridional extent and fronts of the Antarctic Circumpolar Current. Deep-Sea Res. Part I-Oceanogr. Res. Pap., 42, 641-673, doi: 10.1016/0967-0637(95)00021W. [Link]

Park, J., I. S. Oh, H. C. Kim, and S. Yoo, 2010: Variability of SeaWiFs chlorophyll- $a$ in the southwest Atlantic sector of the Southern Ocean: Strong topographic effects and weak seasonality. Deep-Sea Res. Part I-Oceanogr. Res. Pap., 57, 604-620, doi: 10.1016/j. dsr.2010.01.004. [Link]

Peck, L. S., K. E. Webb, and D. M. Bailey, 2004: Extreme sensitivity of biological function to temperature in 
Antarctic marine species. Funct. Ecol., 18, 625-630, doi: 10.1111/j.0269-8463.2004.00903.x. [Link]

Petrou, K., S. A. Kranz, S. Trimborn, C. S. Hassler, S. B. Ameijeiras, O. Sackett, P. J. Ralph, and A. T. Davidson, 2016: Southern Ocean phytoplankton physiology in a changing climate. J. Plant Physiol., 203, 135-150, doi: 10.1016/j.jplph.2016.05.004. [Link]

Platt, T., D. S. Broomhead, S. Sathyendranath, A. M. Edwards, and E. J. Murphy, 2003a: Phytoplankton biomass and residual nitrate in the pelagic ecosystem. Proc. Roy. Soc. Lond. Math. Phys. Sci., 459, 10631073, doi: 10.1098/rspa.2002.1079. [Link]

Platt, T., S. Sathyendranath, A. Edwards, D. Broomhead, and O. Ulloa, 2003b: Nitrate supply and demand in the mixed layer of the ocean. Mar. Ecol. Prog. Ser., 254, 3-9, doi: 10.3354/meps254003. [Link]

Purich, A., W. Cai, M. H. England, and T. Cowan, 2016: Evidence for link between modelled trends in Antarctic sea ice and underestimated westerly wind changes. Nat. Comm., 7, doi: 10.1038/ncomms 10409. [Link]

Smith, R. C., K. S. Baker, and S. E. Stammerjohn, 1998: Exploring sea ice indexes for polar ecosystem studies. BioScience, 48, 83-93, doi: 10.2307/1313133. [Link]

Smith, R. C., D. G. Martinson, S. E. Stammerjohn, R. A. Iannuzzi, and K. Ireson, 2008: Bellingshausen and western Antarctic Peninsula region: Pigment biomass and sea-ice spatial/temporal distributions and interannual variabilty. Deep-Sea Res. Part II-Top. Stud. Oceanogr., 55, 1949-1963, doi: 10.1016/j.dsr2.2008.04.027. [Link]

Smith, W. O., J. Marra, M. R. Hiscock, and R. T. Barber, 2000: The seasonal cycle of phytoplankton biomass and primary productivity in the Ross Sea, Antarctica. Deep-Sea Res. Part II-Top. Stud. Oceanogr., 47, 31193140, doi: 10.1016/S0967-0645(00)00061-8. [Link]

Sprintall, J., 2003: Seasonal to interannual upper-ocean variability in the Drake Passage. J. Mar. Res., 61, 2757, doi: 10.1357/002224003321586408. [Link]

Sullivan, C. W., K. R. Arrigo, C. R. McClain, J. C. Comiso, and J. Firestone, 1993: Distributions of phytoplankton blooms in the Southern Ocean. Science, 262, 18321837, doi: 10.1126/science.262.5141.1832. [Link]

Trimborn, S., C. J. Hoppe, B. B. Taylor, A. Bracher, and C. Hassler, 2015: Physiological characteristics of open ocean and coastal phytoplankton communities of Western Antarctic Peninsula and Drake Passage waters. Deep-Sea Res. Part I-Oceanogr. Res. Pap., 98, 115-124, doi: 10.1016/j.dsr.2014.12.010. [Link]

Vaughan, D. G., G. J. Marshall, W. M. Connolley, J. C. King, and R. Mulvaney, 2001: Climate change: Devil in the detail. Science, 293, 1777-1779, doi: 10.1126/ science.1065116. [Link]

Venables,H.J.,A.Clarke, and M.P.Meredith,2013: Wintertime controls on summer stratification and productivity at the western Antarctic Peninsula. Limnol. Oceanogr., 58, 1035-1047, doi: 10.4319/1o.2013.58.3.1035. [Link]

Vernet, M., D. Martinson, R. Iannuzzi, S. Stammerjohn, W. Kozlowski, K. Sines, R. Smith, and I. Garibotti, 2008: Primary production within the sea-ice zone west of the Antarctic Peninsula: I-Sea ice, summer mixed layer, and irradiance. Deep-Sea Res. Part IITop. Stud. Oceanogr., 55, 2068-2085, doi: 10.1016/j. dsr2.2008.05.021. [Link]

Wang, S., D. Bailey, K. Lindsay, J. K. Moore, and M. Holland, 2014: Impact of sea ice on the marine iron cycle and phytoplankton productivity. Biogeosciences, 11, 4713-4731, doi: 10.5194/bg-11-4713-2014. [Link]

Zhang, H., Z. Han, J. Zhao, P. Yu, C. Hu, W. Sun, D. Yang, G. Zhu, B. Lu, H. U. Peter, and W. Vetter, 2014: Phytoplankton and chlorophyll $a$ relationships with ENSO in Prydz Bay, East Antarctica. Sci. China Earth Sci., 57, 3073-3083, doi: 10.1007/s11430-014-4939-8. [Link]

Zhang, X., S. Liang, G. Wang, Y. Yao, B. Jiang, and J. Cheng, 2016: Evaluation of the Reanalysis Surface Incident Shortwave Radiation Products from NCEP, ECMWF, GSFC, and JMA Using Satellite and Surface Observations. Remote Sens., 8, 225, doi: 10.3390/ rs8030225. [Link] 